特発性血小板減少性紫斑病扣よび

\title{
骨髄線維症の脾摘経験
}

\begin{tabular}{|c|c|c|c|c|c|c|c|c|c|}
\hline 金 & & 秀 & 男 & 勝 & 見 & 正 & 治 & 田 & 伏 克 憞 \\
\hline 河 & 野 & 裕 & 利 & 野 & 口 & 博 & 志 & 青 & 山 \\
\hline 小 & 林 & 康 & 人 & 川 & 嶋 & 寛 & 昭 & & \\
\hline
\end{tabular}

\section{EXPERIENCE WITH SPLENECTOMY IN IDIOPATHIC THROMBOCYTOPENIC PURPURA AND AGNOGENIC MYELOID METAPLASIA}

Hideo KIM, Masaharu KATSUMI, Katsuyoshi TABUSE Hirotoshi KOHNO, Hiroshi NOGUCHI, Osamu AOYAMA

Yasuhito KOBAYASHI and Noriaki KAWASHIMA

Department of Gastroenterological Surgery, Wakayama Medical Coliege

(Director : Prof. Masaharu Katsumi)

1972年 4 月から1982年 3 月までの10年間に当教室で経辆した慢性型ITP脾摘症例は 5 例，骨髄線維症脾摘症例は 2 例（亏ち1 例は小肾例）であった。

脾摘結果を慢性型 ITP 症例については，1）訹前術啳の血小板数の変動，2）術後 corticosteroids 投与の有無，3）術後出血性素因の再発の有無の 3 点上り，また，骨髄線維 症症例については，1）術後脾機能立進症の改善の有無，12）術後合併症の有無，3）脾 腫による隣接脸器の压迫症状の改善の有無の 3 点より検討し、これら 2 疾患の手術適応, 手術時期および脾摘効果に影響を及ぼすと考えられる因子に関し若干の考察を加えた。

\section{I.はじめに}

慢性型特発性血小板減少性紫斑病（以下慢性型 ITP と略す)の治療方針としては，ふつうまず corticosteroids が投与されるが，それに無反応の应例，あるいは 反応してもその投与中止や減量にて再発する症例に対 して脾摘が考虑される。しかしなから，手術時期や手 術に対する反応をどのような方法で予期するか，また corticosteroids 無反応症例に全例手術をすべきかど らかは，未だ解決されていない1．

一方，骨髄線䧽症に脾摘か1 つの治療手段として受 け入れられるようになったのは最近で，主に脾腫によ る王迫症状，お上び随伴する脾機能立進症のために脾 摘を行らものであるが，手術死ならびに術後合併症の 頻度が高率で，その適応に注意深い症例の敩選が必要 とされる゙!.

われわれは，1972年 4 月から1982年 3 月むでの10年
間に，慢性型 ITP の脾摘を 5 例，骨鹃道線維症の脾摘を 2 例（5ち1例は小児）経験し，全例に良好な脾摘結 果が待られたので報告するとともにこれら2疾患の 手術適応，手術時期および脾摘効果に影響を及ぽすと 考えられる因子に関して若干の考察を加える。

\section{II. 対象と方法}

1972年 4 月から1982年 3 月までの10年間に当教室で 脾摘を行った慢性型 ITP 症例は 5 例, 骨䯣線䧽症症例 は 2 例であった。慢性型 ITP 症例の概要を表 1 に示し た。全例女性で，年齢は26〜67歳(平均36.2歳)であっ た。診断時全例著明な血小板数の減少 $\left(<5.0 \times 10^{4} /\right.$ $\left.\mathrm{mm}^{3}\right)$ があり，まず prednisoloneが投与された，投与 方法は，急性期に1～2mg $/ \mathrm{kg} /$ day 与克, 臨床症状と副 作用を考虑に入れ適宜減量ないし中止された，脾摘適 応理由としては，prednisolone 無反応例が 1 例（症例 II)，反応したがその投与中止や減量で出血性素因が再 
表 1 惿性型 ITP 脾揞症例（ 5 例）の概要（1972年 4 月－1982年 3 月）

\begin{tabular}{|c|c|c|c|c|c|}
\hline$=$ 庭例 $\mathrm{Na}$ & I & II & III & IV & $\mathrm{V}$ \\
\hline 生 & 女 & 女 & 女 & 女 & 女 \\
\hline 年命 (†) & 26 & 33 & 26 & 29 & 67 \\
\hline 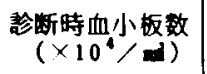 & 4.0 & 3.7 & 4.4 & 2.9 & 2.6 \\
\hline 主要 拝 状 & $\begin{array}{l}\text { 紫㘪 } \\
\text { 整肉出血 } \\
\text { 性器出血 }\end{array}$ & 紫暗 & $\begin{array}{l}\text { 柴㸚 } \\
\text { タール便 } \\
\text { 月経過多 }\end{array}$ & $\begin{array}{l}\text { 紫斑 } \\
\text { 生器出血 } \\
\text { 月経過多 } \\
\text { 出血 }\end{array}$ & $\begin{array}{l}\text { 紫斑 } \\
\text { 锠出血 }\end{array}$ \\
\hline 脾摘適応理由 & $\begin{array}{l}\text { *.H.の减量 } \\
\text { ないし中止 } \\
\text { で出血素因 } \\
\text { 再発 }\end{array}$ & $\begin{array}{l}\text { ․H.に反応 } \\
\text { せず }\end{array}$ & $\begin{array}{l}\text { s.H.の咸量 } \\
\text { ないし中代 } \\
\text { で出向素因 } \\
\text { 再発 }\end{array}$ & $\begin{array}{l}\text { s.H.の諴量 } \\
\text { ふいし中止 } \\
\text { で出血素因 } \\
\text { 再発 }\end{array}$ & $\begin{array}{l}\text { S.H.の減量 } \\
\text { ふいし中止 } \\
\text { で出血素因 } \\
\text { 再発 }\end{array}$ \\
\hline $\begin{array}{l}\text { 術前治癔 } \\
\text { 1)プレドニドロン } \\
\text { 2)俞血（全血） } \\
\text { 3)アザチオプリン }\end{array}$ & $\begin{array}{l}+ \\
+ \\
-\end{array}$ & $\begin{array}{l}+ \\
+ \\
+\end{array}$ & $\begin{array}{l}+ \\
- \\
-\end{array}$ & $\begin{array}{l}+ \\
+ \\
+\end{array}$ & $\begin{array}{l}+ \\
+ \\
-\end{array}$ \\
\hline 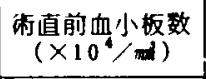 & 9.7 & 8.6 & 12.0 & 5.4 & 14.6 \\
\hline 病 畄 期 間 & 7 ケ月 & ムケ月 & 1 年 2 ケ月 & 3 年 4 ケ月 & 1 ○ケ月 \\
\hline
\end{tabular}

発したすのが 4 例(症例 I，III, IV，V）であった。 病㥗期間は 4 力月一 3 年 4 力月（平均 1 年 3 ケ月）て あった。なお，兔疫抑制隹である azathioprineが, prednisolone 無反応例（症例II）之, 病恼期間が長期 に亘った例（症例IV）に併用された。全例術直前には

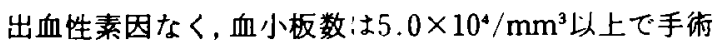
が施行された。また，prednisolone は術前 2 週頃より 斬城投与され，術直前に投与が中止されたが，症例 V は胃癌合併例のため prednisolone 続行のまま手術を 施行した。なお，血小板輸血は全释過を通じ使用され ず，全血輸血か４例（症例 I，II，IV，V）に使用さ れた。次に，骨髄線維症症例の概要を表 2 に示した。 症例 Iは26歳の女性で, 脾摘適応理由は, 間歇的に脾 機能六進症が出現し，頻回に輸血をくり返さればなら なかったためである。脾摘は，corticosteroidsおよび androgensにより脾腫の樎少と一般挨血の正常化した 時期に施行された。症例IIは 4 藏 9 カ月の女児で，小 児科で精查するも術前確診がつかす，巨大脾腫の破裂
の危惧にて紹介され脾摘を行った。術前著明な汎血球 减少があり，術前・術中を通じて成分輸血により補正 をしながら手術が施行された。病悩期間は症例 I が 3 年 5 ケ月，应例 IIが 1 年であった。

以上の症例を対象とし，慢性型 ITP 症例について は, 1) 沭前術㣪の血小板数の変動，2）術後 corticos. teroids 投与の有無, 3) 柿後出血性素因の再発の有無 の3 点より，また骨䯙線維症症例については，1 術後 脾機能六進症の改善の有無，2 術後合併㱏の有無，3） 脾腫による隣接缄器の王迫症状の改善の有無の 3 点よ り脾摘結果を検討した。

\section{III. 結 果}

\section{A. 慢性型 ITP 症例（ 5 例）}

手術所見，術後合併症およで術後船過を表 3 に，術 前術後の血小板数の変動を図 1 に示した。摘出脾重量 は90 - 330g (平均 $165 \mathrm{~g}$ ) で，副脾か; 2 例（症例UI，IV) にみられた。術後合併症は，1例（症例 I）に軽い不 正性器出血，1例（症例IV）に短期間の熱がみられ。 
表 2 骨鲢線維症脾摘症例（２例）の概要（1972年 4 月 - 1982年 3 月)

\begin{tabular}{|c|c|c|}
\hline - & I & II \\
\hline 性 & 女 & 女 \\
\hline 年令 $(わ)$ & 26 & 4.75 \\
\hline 主要往状 & 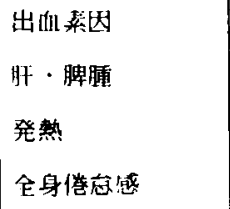 & $\begin{array}{l}\text { 巨大脾婳 } \\
\text { 肝腄 } \\
\text { 溶血発作 } \\
\text { 発熱 }\end{array}$ \\
\hline 腄摘適応理由 & 脾機能几進拄 & $\begin{array}{l}\text { 巨大脾陣の破裂の } \\
\text { 危惧 }\end{array}$ \\
\hline 術前治竸 & $\begin{array}{l}\text { 1) Corticosteruids } \\
\text { 2) Androgens } \\
\text { 3) 䑳血 }\end{array}$ & $\begin{array}{l}\text { 1) 輸血l } \\
\text { 2) Curticosteroud }\end{array}$ \\
\hline 病悩期間 & 3 年 5 个月 & 1 年 \\
\hline $\begin{array}{l}\text { 術直前 } \\
\text { 汎血球城少 }\end{array}$ & - & + \\
\hline
\end{tabular}

1 例（症例 V）に左横隔膜下膿瘍がみられた，術前 corticosteroidsに対してよく反応した 4 例（症例 I， III，IV，Vは，術後 corticosteroids 投与なしで，出 血性亲因の出現なく，また血小板数も常時 $10.0 \times 10^{4} /$ $\mathrm{mm}^{3}$ 以上に維持され良好な脾摘結果が得られた。しか しながら，图 1 に示した如く病脳期間が長期に亘った 症例IVは術直後の血小板数が $10.0 \times 10^{4} / \mathrm{mm}^{3} \frac{1}{1}$ でもの 回復がやや悪かった。一方，術前 corticosteruidsに無 反応であった 1 例（症例II）は，術後約 1 年 6 ケ月の 間時々点状出血があり prednisolone の間歇投与を受 けたが，それ以後 7 年結過した現在まで corticosteroids 投与なしで出血性素因の再発なく。血小顺数 $10.0 \times 10^{4} / \mathrm{mm}$ 以上に維持され良好な脾摘結果が得ら れたが，図1に示した如く，術直後の血小板数は $10 \times$ $10^{4} / \mathrm{mm}^{3}$ 台に止まり，一般に脾摘直後に見られる急激 な上昇はなかった。

\section{B. 骨㩆線維症症例 ( 2 例)}

手術所見, 術後合併症および術後経過を表 4 に, 術 前術後の一般娭血の变動を图 2 に示した。摘出脾重量 は, 症例 I にみられた。症例 I は術後合併症なく，脾機能六進症 あ改善され，9年 2 ケ月経た現在, 原疾患に対する保 存的療法にて順調に経過中である. 症例II 術後合併 症なく，約 1 年経大現在，原疾患によると考えられる
表 3 慢性型 ITP 脾摘症例（５例）の手術所見，術後 合併症およひ術後経過

\begin{tabular}{|c|c|c|c|c|c|}
\hline 位例Na & I & II & III & IV & $\mathrm{v}$ \\
\hline 手術所見 & & & & & \\
\hline 掊出雾重 $(0)$ & 100 & 185 & 118 & 330 & 90 \\
\hline 咻睓 & - & - & + & + & - \\
\hline 行徏合垪拉 & + & - & - & + & + \\
\hline 訹後経過 & & & & & \\
\hline 出血素因再発 & - & + & - & - & - \\
\hline Corticosteroids 投与 & - & + & - & - & - \\
\hline 追 跡 期 間 (年) & 8 & 7 & 3 & 1.5 & 0.25 \\
\hline
\end{tabular}

表4骨随線維症脾摘症例（２例）の手術所見, 術後 合併症および術啳経過

\begin{tabular}{|c|c|c|}
\hline$=$ 佂例N & I & II \\
\hline 手術所見 & & \\
\hline 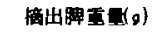 & 300 & 1400 \\
\hline 副䏷 & - & + \\
\hline 街後合併庭 & - & - \\
\hline 術後程過 & & \\
\hline 讵血球娍少征 & - & - \\
\hline 追跡期間 & 9 年 2 ケ月 & 1 年 \\
\hline
\end{tabular}

間歇的発熱と腰痛，ならびに肝腫の増大があるも，巨 大脾腫による王迫症状は改善された，また，汎血球减 少む改善され，現在は原疾患によると考えられる赤血 球数，血小板数の軽度減少之白血球の分画異常を認め るだけで，容血発作も消失した，2症例とも術後合垪 症なく，また脾機能え進症および脾腫に上る隣接缄器 の压迫症状る改善され良好な脾摘結果が得られた。

\section{IV. 考 案}

\section{A. 慢性型 ITP の脾摘について}

慢性型 ITPの治療方針はふつら图 3 に示されたフ ロトコールに沿って行われる゙。.すなわち，まず corticosteroids が投与され，無効例また恃再発例に対し て脾摘が考慮される。われわれの 5 症例もこの方針に 沿い脾摘が行われた．脾摘効果の判定は報告者により 多少の相異はあるが，1）術前術後の血小板数の变動， 2) 術後 corticosteroids 投与の有無, 3) 訹後出血素因 の有無の 3 点より判定され，われわれも同様に判定を 行い全例に良好な結果を得たのは前述した通りであ る.ふつう corticosteroids のみで完全宽解が得られる のは，慢性型 ITP で15 60\%であるとされ，多くの婸 


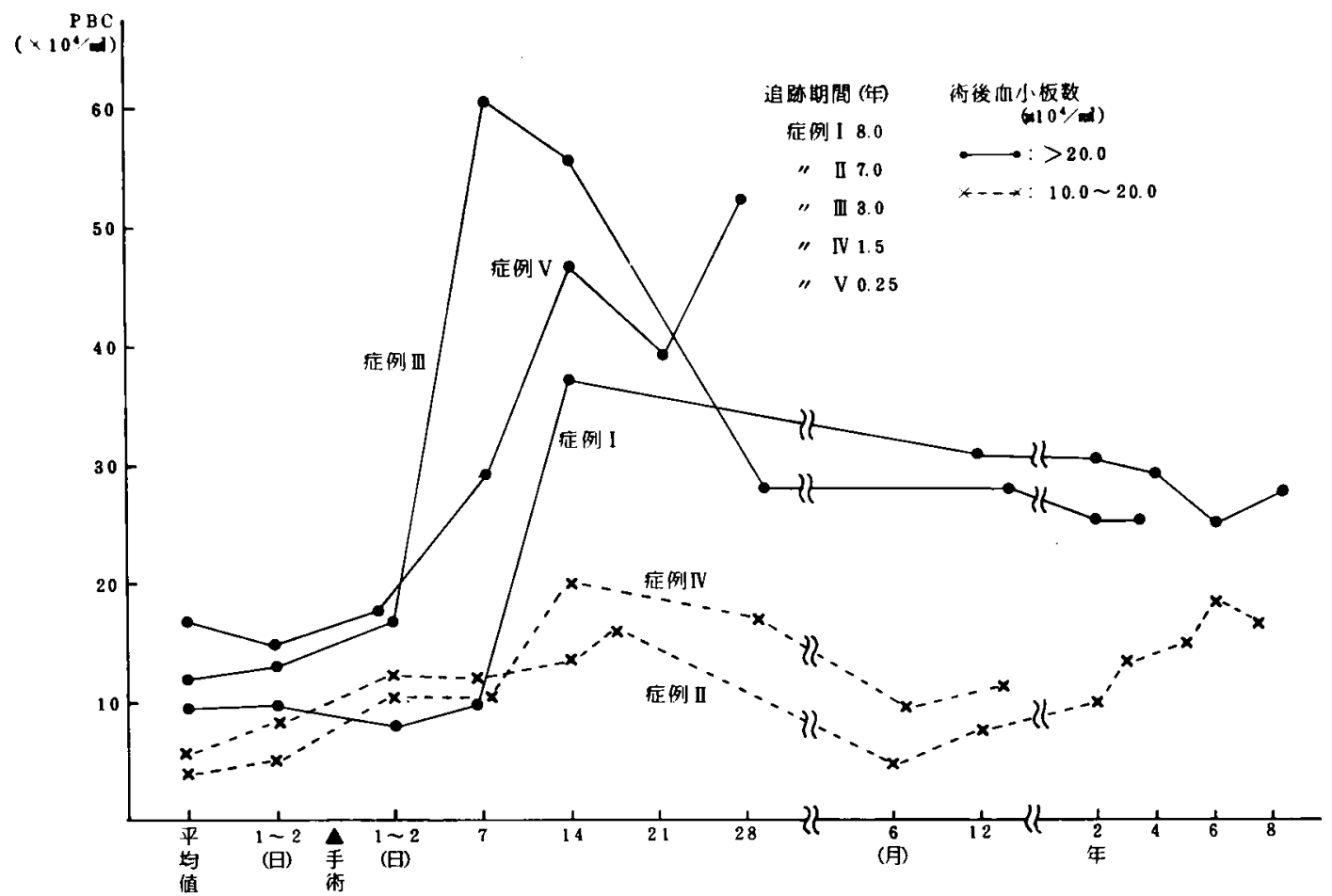

図 1 慢性型 ITP 脾摘症例（5 例）の術前術後の血小板数の变動
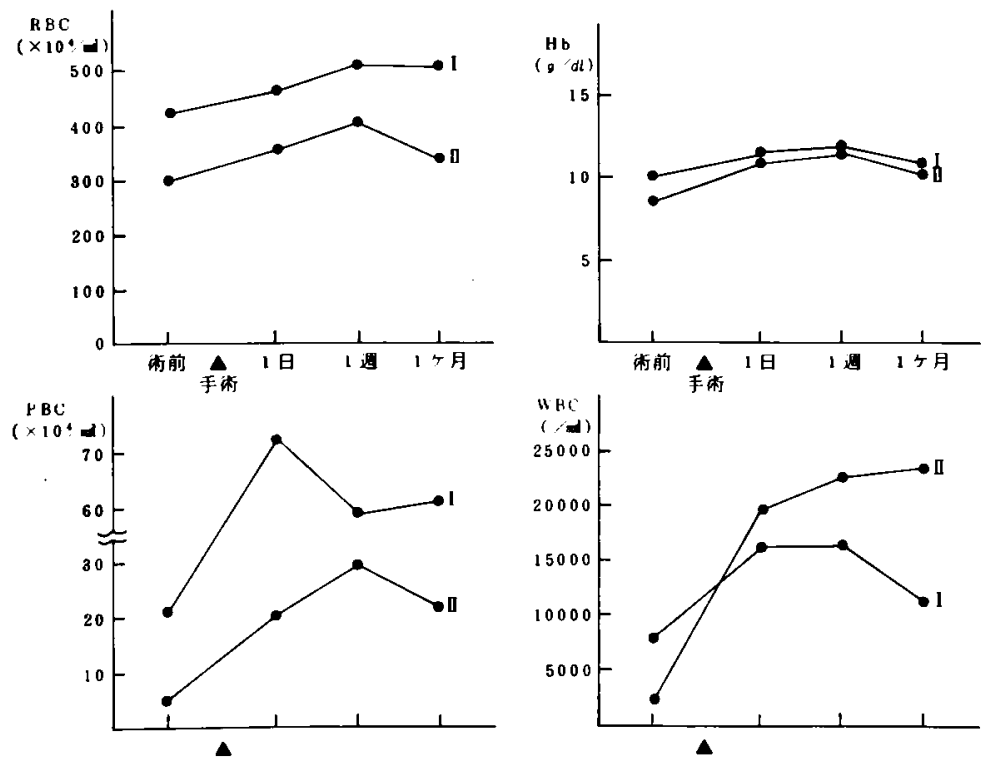

図 2 骨鲢線維症脾摘症例（2 例）の衍前術後の一般検血の变功

合一過性に反応するのみで，脾摘が最も有効かつ確実 な方法で約70～80\%に完全寞解が得られてい る(4) 10). しかしながら，手術時期の決定，脾摘無効例
に対する術前の予測, および corticosteroids 無反応例 に全例手術をすべきかどうかは未だ解決されていな (.11). 

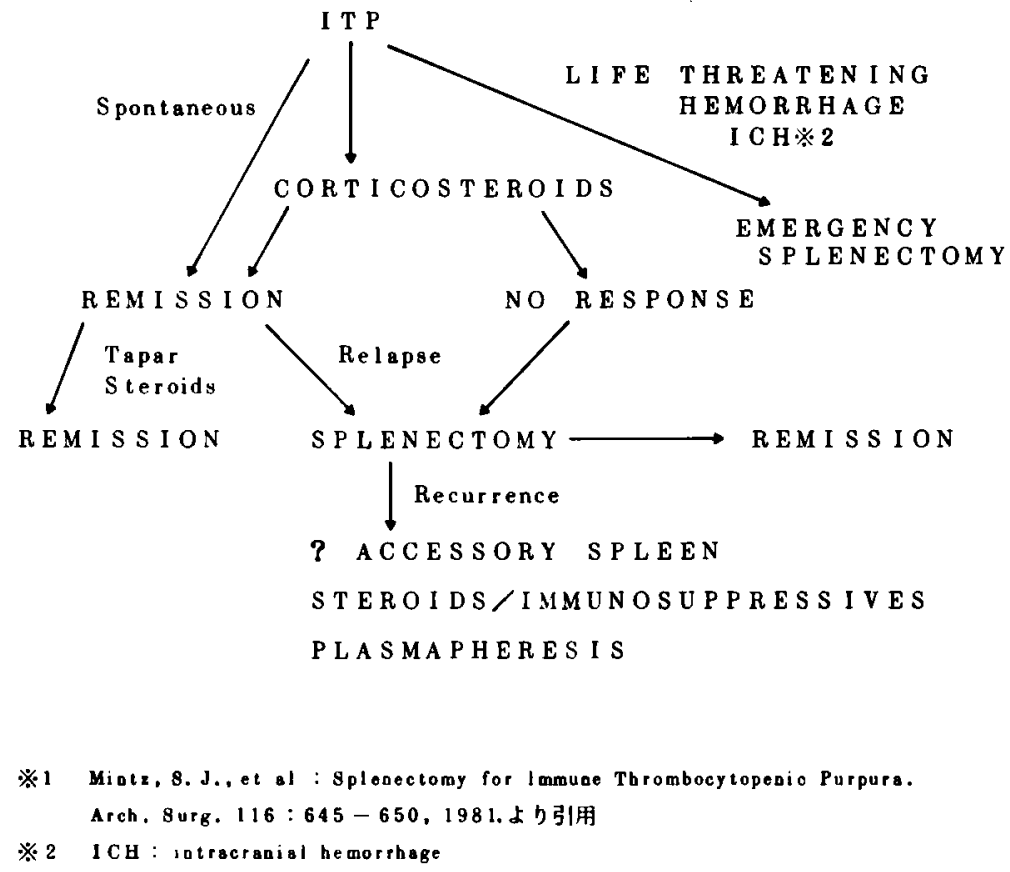

园 3 Protocol for treating patients with ITP 1

手術時期については，Ahn ら ${ }^{121}$ が脾摘効果は病脑期 間のより短い症例によかったと報告しているように， われわれの例でも，病脳期間が長期に亘った症例IVで 術後血小板数の回復がやや悪かったことから，手術を 避けるため術前に corticosteroidsを長期に大量使用 することは，副作用ならびに手術への影響をす考虑に 入れ避けるべきである。しかしながら, corticosteroids に対する有効・無効の判定は困難で，Butoianu ${ }^{13)} に よ$ れば, $2 \sim 4$ 週以上, $1.0 \sim 1.5 \mathrm{mg} / \mathrm{kg} /$ day $の$ prednisoloneで適当な血小板数が得られないとき常に治 療効果なしとして脾摘を勧めており，またKoller ${ }^{111} に$ よれば，15mg/day 以上，6週以上の corticosteroids 投与を必要とする場合は，その投与の合目的な中止の 場合で脾摘を行らへきと示唆している。一方，われわ れの 4 症例(症例 I, III, IV, V)のよ5に, corticosteroidsによく反応し，早期にその投与减量や中止が出来 たにもかかわらず出血性素因の再発および血小板数减 少をくり返しみる例に対しては，その手術時期および 手術決定には種々の観点より困難がつきを られる。.上上の如く，術前の corticosteroids 投与の効 果判定ならびに手術時期の決定には現在一致した見解 はなく，次に述べる脾摘効果を予測する術前因子とと もに今後さらに検討される点であろう。
従来より脾摘効果を予測する上で，㭪前の corticosteroidsに対する反応態度，性・年龄，骨髓中の巨核球 数とその形態，血小板寿命，および抗血小板抗体価な どょり検討されてきたが，一定の見解がないのが現状 である.なかでも術前の corticosteroidsに対する反応 と脾摘効果とが正の相関をするといらことが多くの報 告でみられ の結果を得た。しかし逆に明白な関係がないとする報 告るみられ311，われわれの例でる，術前 corticosteroids に対し無反応であった症例 II が，術後血小板数 $10.0 \times 10^{4} / \mathrm{mm}^{3}$ 台でその回復がやや悪かったが良好な 脾摘結果が得られている. 術直前の血小板数について は，安全に手術が施行されるためにも，ふつ55.0X $10^{4} / \mathrm{mm}^{3}$ 以上必要上され3), われわれの症例。 4 例(症 例 I， III, IV, V)は corticosteroidsにより，1例(症 例II）は免疫抑制剤である azathioprineにより術直前 $5.0 \times 10^{4} / \mathrm{mm}^{3}$ 以上で手術が施行され，術中・術後に出 血によるトラプルるなく良好な脾摘結果が得られたよ $5 に$ ，術前に corticosteroids，免疫抑制用，血小板榆 血等により積極的に血小板数を上昇せしめた時点で手 術を行らことは重要な点であると考えられた ${ }^{13)}$.

術前の corticosteroids 無反応例については, 最近の 報告によると，脾摘をしなかった患者に比し，脾摘を 
以前に受けた患者の方か，corticosteroids や免疫抑制 剂によく反応寸る10141 と述へらられているよ5に、睡摘 法手術の絶対禁忌がなければ，慢性型 ITP 患者にとっ ては、術前の corticosteroidsに対する反応にかかわら す、、今後 preffered treatment になるであろらとしてい る3.。われわれの症例中, corticosteroids 無反応例(症 例II）去，免废抑制郕である azathioprineにより術前 血小板の上昇が得られた例で，結果的に良好な脾摘効 果を得. Srichaikal ら ticosteroids とともに，他の免度抑制剂の術前投与む また有用になるであろらと考えられた 1 症例である。

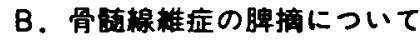

常に脾腫を伴い，しばしば機能的ないし機械的障害 を引き起こす骨蹃線雃症患者の治瘄における脾摘の役 割は，この垁患がMPD (myeloproliferative disorders）の籍即に入れられるようになって以来議論の 的になってきた。初期の頃は，㭪後合併症お上び死亡 率が非常に高く、また血液学的にす臨床的にす改善が 活とんどみられなかったか，過去25年以上に亘ってこ の垁患に対する脾摘の有効性についても報告されてき た16).しかしながら、末た術後合併店および死亡率が高 く”，蓑た手術・非手術例で，診断以降の生存期間中死 亡原因においてはとんど差をみないとする報告もあ $\eta^{2116)}$, 脾摘道応，手術時期の決定，および脾摘の目的・ 奻果を有奻かつ安全に行うためには傎重な配慮が必要 とされている17181.

脾摘適応理由の主なるのは，巨大脾腫による隣接践 器の王迫症将の改善と, 脾機能六進症からくる血小板

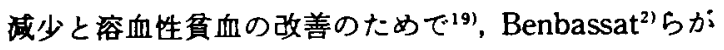
集計した321例中，約65\%にその有効性がみられてい る.しかしながら，1970年以降の71例中 5 例 $7 \%$ )か 術後 2 日以内に死亡し, 術後 3 ケ月以内に 20 例 $28.2 \%$ )か死亡しているように，他の血液矣患患者に おける脾摘に比し明らかに高い死亡率となっている。 この理由として，手術適応としてあげられる頜血，血 小板减少抢よび巨大脾畽それ自身が進行した時期にあ り，術後合併症および死亡率を高めているといらこと が指摘されてきた21. 従って手術時期として，診断がつ 当㳄第手術を行った方が㭪後合併症および死亡率は低 いとする報告が多い20121。また，Crosby らは，脾機能 亢進症を初期の骨睢線維症における脾摘は有益て あろらと述べたが，この仮説は今日まで実証されてい ない17.われわれの症例 I は，間歇的脾機能六進症のた め脾摘を行い，血夜学的にも臨床的にむ良好な結果を
得たわけであるが，原矮患の程度が俥症であったため か，保存的寮法によく反応したためかは不明であるが， 衍前脾機能六進㱏ならびに脾畽がよくコントロールさ れ、病脳期間が 3 年 5 ケ月と長期に亘った例で，この よらな例では，診断がつき次第脾摘を行わなくてる良 好な脾摘結果が得られると考えられた。应例IIは，巨 大脾腫の破裂の危惧にて脾摘を行った例で，術前著明 な汎血球减少す認められたが術後合併症すなく良好な 脾摘効果が得られた。これは，手術手技の改良ならび に術前術後の管理の進歩によるるのと考兵られ, 進行 した時期の患者でる積的に脾摘が行い得ると考えら れた。

骨随線維症患者における脾摘の目的・効果を有効か つ安全に行らため, 従来より年龄, 性 ${ }^{19}$, 脾重量, 病脳 期間, 術前の血小板数 - 血色素量 - 血清 ALP 值, Ferrokinetics ${ }^{16)}$, 赤血球寿命, 骨噵所見等上り検討さ れてきた. Benbassat ${ }^{2}$ らは、詳細に術後生存率および 死亡峯より，患者選択のための基準設定を試み，術前 血小板数・血清 ALP 值および脾重量よりその差を見 い出しているが、結論としては各々の症例につき評価 し，手術による思恵の方がそのリスクにまさるときに 手術はなされるべきとしているように，患者の選択は むずかしく，今後さらに症例を重好て検討していく必 要性があろう。

\section{V. とぬ}

1972年 4 月から1982年 3 月までの10年間に当教室で 経験した慢性型 ITP の腫摘例（5例）と骨䯣線維症の 脾摘例（2 例，5ち 1 例は小児例）を報告するととも に，これら2疾患の手術通底，手術時期および脾摘効 果に影䈉を及ぼすと考えられる点などを中心に若干の 考察を加えた。

\section{Reference}

1) Ikkala, E., Kivilaakso, E., Kotilainen, M., et al. : Treatment of idiopathic thrombocytopenic purpura in adults. Ann. Clin. Res., $10: 83-86,1978$.

2) Benbassat, J., Penchas, S. and Ligumski, M.: Splenectomy in patients with agnogenic myeloid metaplasia : an analysis of 321 published cases. Br. J. Haematol., 42 : 207-214, 1979.

3) Mintz, S.l., Petersen, S.R., Cheson, B., et al.: Splenectomy for immune thrombocytopenic purpura. Arch. Surg., 116 : 645-650, 1981.

4) Heaton, A., Jacob, P., Dent, D.M., et al.: Experience with splenectomy in auto-immune 
thrombocytopenia and agnogenic myeloid metaplasia. SA Medical Journal, 50: 1506 -1512. 1976.

5) Schwartz, S.I., Hoepp, L.M. and Sachs, S. : Splenectomy fo thrombocytopenia. Surgery, 88 : 497-506, 1980.

6) Block, G.E., Evans, R. and Zajtchuk, R. : Splenectomy for idiopathic thrombocytopenic purpura. Arch. Surg., 92 : 484-489, 1965.

7) Carpenter, A.F., Wintrobe, M.M., Fuller, E.A., et al.: Treatment of idiopathic throm. bocytopenic purpura. J.A.M.A., 171: 1911 -1916, 1959.

8) Thompson, R.L., Moore, R.A., Hess, C.E., et al. : Idiopathic thrombocytopenic purpura: LongTerm results of treatment and the prognostic significance of response to corticosteroids. Arch. Intern. Med., 130 : 730-734, 1972.

9) Jiji, R.M., Firozvi, T. and Spurling, C.L. : Chronic idiopathic thrombocytopenic prupura. Arch. Intern. Med., 132 : 380-383, 1973.

10) Karpatkin, S.: Autoimmune thrombocytopenic puprua. J. Am. Soc. Haem., $56: 329$ $-343,1980$.

11) Koller, C.A. : Immune thrombocytopenic purpura. Med. Clin. North. Am., $64: 761-773,1980$.

12) Ahn, Y.S. and Harrington, W.J.: Treatment of idiopathic thrombocytopenic purpura. Ann. Rev. Med., 28 : 299-309, 1977.

13) Butoianu, E. and Berceanu, S.T.: Present-day problems of diagnosis and treatment in the idiopathic thrombocytopenic purpura. Med.
Int., $18: 15-24,1980$.

14) Caplan, S.N. and Berkman, E.M.: Im. munosuppressive therapy of idiopathic throm bocytopenic purpura. Med. Clin. Am., 60: 971 $-986,1976$.

15) Srichaikal, T. and Boonpucknavig, S. : Chronic immjnologic thrombocytopenic purpur. a. Results of cyclophosphamide therapy before splenectomy. Arch. Intern. Med., 140 : 636-638, 1980.

16 Cabot, E.B., Brennan, M.F., Rosenthal, D.S., et al. : Splenectomy in myeloid metaplasia. Ann. Surg., $187: 24-30,1977$.

17) Ward, H.P. and Block, M.H.: The natural history of agnogenic myeloid metaplasia and a critical evaluation of its relationship with the myeloploliferative syndrome. Medicine, $50: 357$ -419, 1971.

18) Silverstein, M.N. and ReMine, W.H.: Sex, splenectomy and myeloid metaplasia. J.A.M.A., 227 : 424-425, 1974.

19) Silverstein, M.B. and ReMine, W.H. : Splenectomy in myeloid metaplasia. Blood, 53 : 515-518, 1979.

20) Mulder, H.. Steenbergen, J. and Haanen, C. : Clinical course and survival after elective splenectomy in 19 patients with primary myelofibrosis. Br. J. Haematol., 35: 419-427, 1977.

21) Crosby, W.H., Whelan, T.J. and Heaton, L.D. : Splenectomy in the elderly. Med. Clin. North. Am., 50 : 1533-1558, 1966. 